\title{
Effects of Therapy on Anterior Pituitary Functions in Patients with Primary Intracranial Germ Cell Tumor
}

\author{
Atsushi KUMANOGOH, Soji KASAYAMA, Haruhiko KOUHARA, \\ MaSAFumi KOGA, Norio ARITA*, TORU HAYAKAWA*, \\ TADAMITSU KISHIMOTO, and Bunzo SATO \\ Departments of Medicine III, and *Neurosurgery, Osaka \\ University Medical School, Osaka 565, Japan
}

\begin{abstract}
Intracranial germ cell tumors are known to be frequently associated with anterior pituitary hypofunction and diabetes insipidus. In general, these manifestations are not ameliorated even after successful radiotherapy. Since platinum based chemotherapy is introduced as a therapeutic approach to these tumors, its effectiveness is compared with the outcome obtained by radiotherapy in terms of tumor regression and endocrine functions. In this study, six patients received conventional radiotherapy and one received chemotherapy as an initial treatment. In all patients, complete remission was achieved irrespective of the therapeutic method. Their diabetes insipidus was not improved. Many patients treated with radiotherapy did not show the complete improvement of pre-existing hypofunction of the anterior pituitaries. In contrast, chemotherapy achieved almost complete hormonal remission. These clinical observations suggest that chemotherapy is quite effective in oncological as well as endocrinological aspects in treating intracranial germ cell tumors.
\end{abstract}

Key words: Intracranial germ cell tumors, Radiotherapy, Chemotherapy, Hormonal remission.

(Endocrine Journal 41: 287-292, 1994)

INTRACRANIAL germ cell tumors mainly occur in adolescents and young adults, and their incidence is relatively high in Japan, being calculated to be 2.1 to $9.4 \%$ of all intracranial neoplasms occurring in adolescents and young adults [1, 2]. According to cells of origin, germ cell tumors can be divided into germinoma and non-germinomatous germ cell tumor (teratoma, embryonal cell carcinoma, choriocarcinoma, endodermal sinus carcinoma and mixed germ cell tumors) [3]. These tumors occur in the midline, principally in the pineal area or anteriorly around the suprasellar region. These localizations and their invasiveness may be associated with the well-characterized clinical observation that a variety of endocrinological abnor-

Received: October 21, 1993

Accepted: February 15, 1994

Correspondence to: Dr. Bunzo SATO, Department of Medicine III, Osaka University Medical School, 2-2 Yamada-oka, Suita-shi 565, Japan malities are observed in patients with germ cell tumors $[4,5]$. This is true even though the tumors arise from the pineal region [5].

These tumors have, until recently, been extensively irradiated. This therapeutic method has achieved the relatively high five-year survival rate (35-85\%) [6]. However, some types of these tumors such as the non-germinomatous germ cell tumor were observed to be resistant to conventional radiotherapy $[7,8]$. Another disadvantage is that radiotherapy is causally related to the permanent dysfunction of the anterior pituitary gland [9]. In view of the ages of the patients with these tumors, this endocrine aspect seems to be important. But this is almost always ignored, probably due to their malignant nature.

Accumulating evidence related to effective chemotherapy used for testicular germ cell tumors [10, 11] has lead to the introduction of platinum-based chemotherapy as a therapeutic approach to intra- 
cranial germ cell tumors. Actually, chemotherapy has been reported to be successfully used in treating intracranial germ cell tumors. The overall response rate exceeds $90 \%[12,13]$. However, the chemotherapy-induced changes in endocrine functions remain to be clarified. The present clinical observations raise an interesting possibility that chemotherapy is quite effective in achieving excellent hormonal remission with simultaneous tumor regression.

\section{Patients and Methods}

\section{Patients}

Seven patients with primary intracranial germ cell tumors were studied. The patients' clinical characteristics including age, sex, therapeutic methods are summarized in Table 1. This diagnosis was made by histological investigation of biopsied specimens (Cases Nos. 2, 3, 5 and 6) or by cytospine analysis of their cerebrospinal fluid (Cases Nos. 1, 4 and 7). Since the three patients whose diagnosis was not confirmed by histological examination were included in the present study, tumor markers were also taken into consideration to diagnose the subtype of intracranial germ cell tumor [6, 14, 15]. All patients underwent radiological examination by computed tomographic scan (CT) and/or magnetic resonance imaging (MRI). Informed consent was obtained from the patients or from their parents.

Six patients were irradiated at total doses of 50 Gy (30 Gy to whole brain followed by $20 \mathrm{~Gy}$ to tumor region) and 0-20 Gy to whole spine as a primary treatment. One patient (Case 6) was treated with three cycles of combined chemotherapy (CBDCA + etoposide) as an initial therapeutic method (vida infra).

\section{Methods}

Serum levels of pituitary hormones (TSH, GH, LH, FSH, PRL), thyroid hormones, cortisol (F), testosterone and tumor markers (human chorionic gonadotropin (HCG) and $\alpha$-fetoprotein (AFP)) were measured by commercially available radioimmunoassay kits (Daiichi Isotope Co., Ltd.) as described previously $[6,16]$. To determine the basal levels of these hormones, blood was drawn from each patient at $0800 \mathrm{~h}$. The presence of placental alkaline phosphatase (ALP) in the cerebrospinal fluid was also examined [15]. To evaluate the residual hormone secreting capacity of the anterior pituitary gland, triple load test (intravenous injection of insulin $(0.1 \mathrm{u} / \mathrm{kg}$ body weight), TRH (500 $\mu \mathrm{g})$ and $\mathrm{GnRH}(100 \mu \mathrm{g})$ at $0800 \mathrm{~h}$ ) was carried out.

\section{Results}

Both radiotherapy and chemotherapy achieved complete remission (CR) in all patients examined, as judged by their radiological findings (Table 1). Serum levels of tumor markers (HCG and AFP) were also reduced to the normal ranges in response to these therapies (data not shown). The adverse effects elicited by these therapeutic methods were clinically tolerable. In all patients, however, pre-existing diabetes inspidus (DI) was not ameliorated and did require the continued intranasal administration of antidiuretic hormone. Endocrinological evaluation of anterior pituitary functions was also made before and after the treatment. Abnormal basal concentrations of hormones were identified in many patients. The impaired release of pituitary hormones in response to triple load test was also observed in all patients at the pretherapeutic stage, even though two patients (Patients 1 and 7) did not have a tumor at the sellar or supracellar region. Overall, six patients revealed abnormal serum levels of more than one pituitary hormone. No accurate endocrinological estimation could be made of the remaining one patient (Patient 4) since he had received a pharmacological dose of betamethasone. After therapies, the response of GH to hypoglycemia was moderately improved in two patients (Patients 5 and 6). The pro-existing adrenocortical hypofunction was ameliorated in Patients 3 and 6 by the therapies. The improvement in the adrenocortical function in Patient 3 was transient, and glucocorticoid replacement therapy was ultimately required to overcome his adrenocortical hypofunction. In addition, the impaired release of TSH, GH and gonadotropins remained unchanged in Patient 3. In general, radiotherapy caused more deteriorated responses to TRH stimulation than those obtained in the pretherapeutic stage. The peak values for gonadotropins induced by GnRH stimulation were lowered or not ameliorated by radiotherapy except for $\mathrm{Pa}$ - 
Table 1. Clinical characteristics of the patients

\begin{tabular}{|c|c|c|c|c|c|c|c|c|}
\hline $\begin{array}{l}\text { Patient } \\
\text { No }\end{array}$ & $\begin{array}{c}\text { Sex/ } \\
\text { Age(yr) }\end{array}$ & Primary Site & Diagnosis & Treatment $R$ & Response & $\begin{array}{c}\text { Outcome } \\
\text { (follow-up period) }\end{array}$ & Comment & Tumor Marker \\
\hline 1 & $\mathrm{M} / 29$ & Pineal & Germinoma ${ }^{a}$ & Radiation & CR & $\begin{array}{c}\text { alive with no relapse } \\
(9 \mathrm{yr})\end{array}$ & & none \\
\hline 2 & $\mathrm{M} / 23$ & $\begin{array}{c}\text { Pineal }+ \\
\text { Bilateral frontal lobes }\end{array}$ & Germinoma & Radiation & $\mathrm{CR}$ & $\begin{array}{l}\text { alive with no relapse } \\
\text { (15 yr) }\end{array}$ & porencephalus & none \\
\hline 3 & $\mathrm{M} / 25$ & Suprasellar & $\begin{array}{l}\text { Embryonal cell } \\
\text { carcinoma with } \\
\text { Choriocarcinoma }\end{array}$ & Radiation & CR ali & $\begin{array}{l}\text { live with relapse at } 35 \mathrm{mo} \\
\qquad(5 \mathrm{yr})\end{array}$ & & $\begin{array}{c}\text { HCG, } \\
\text { placental } \\
\text { ALP }\end{array}$ \\
\hline 4 & $\mathrm{M} / 21$ & Pituitary Stalk & Germinoma $^{a}$ & Radiation & $\mathrm{CR}$ & $\begin{array}{l}\text { alive with no relapse } \\
(20 \mathrm{mo})\end{array}$ & & none \\
\hline 5 & $\mathrm{~F} / 20$ & Suprasellar & $\begin{array}{l}\text { Germinoma with } \\
\text { Choriocarcinoma }\end{array}$ & Radiation & $\mathrm{CR}$ al & $\begin{array}{l}\text { live with relapse at } 8 \mathrm{mo} \\
\qquad(26 \mathrm{mo})\end{array}$ & & HCG \\
\hline 6 & $\mathrm{M} / 21$ & $\begin{array}{c}\text { Pineal + } \\
\text { Pituitary Stalk }\end{array}$ & $\begin{array}{c}\text { Germinoma with } \\
\text { Embryonal cell } \\
\text { carcinoma }\end{array}$ & Chemotherapy & y $C R$ & $\begin{array}{l}\text { alive with no relapse } \\
(10 \mathrm{mo})\end{array}$ & & HCG, AFP \\
\hline 7 & $\mathrm{M} / 13$ & Pineal & Non-germinoma ${ }^{a}$ & Radiation & $\mathrm{CR}$ & $\begin{array}{l}\text { alive with no relapse } \\
\qquad(4 \mathrm{mo})\end{array}$ & & HCG \\
\hline
\end{tabular}

a, No histological confirmation was made; $b$, Tumor is mainly composed of germinoma cells.

tient 5. However, Patient 5 ultimately have panhypopituitarism after transient improvement. On the other hand, chemotherapy markedly improved the ability of his anterior pituitary to release TSH. The responses of gonadotropins to $\mathrm{GnRH}$ stimulation were also ameriolated by chemotherapy in Patient 6 (Table 2). His serum levels of $\mathrm{F}$ in the basal as well as the hypoglycemic state were also increase to the normal range after successful chemotherapy. Particular attention was therefore paid to Patient 6.

This patient with DI and gynecomastia was admitted to Osaka University Hospital. After he was diagnosed as having an intracranial mixed germ cell tumor (germinoma with embryonal cell carcinoma component) by radiological, histological and oncological findings (see Table 1), he was treated with CBDCA $(300 \mathrm{mg} /$ body surface area $\left(\mathrm{m}^{2}\right)$ and etoposide $(60 \mathrm{mg} /$ body surface area $\left.\left(m^{2}\right)\right)$. CBDCA was given on day 1 and etoposide was consecutively given for 5 days. The patient received three cycles of this chemotherapy at 4 week intervals. This combination chemotherapy achieved complete remission, judged by the findings of the MRI study (Fig. 1). Before chemotherapy his serum levels of many hormones including LH were in abnormally low ranges. His testosterone level was normal, probably due to the fact that Leydig cells could respond to tumor- derived HCG. In line with this speculation, both testosterone and HCG were gradually decreased after initiating the chemotherapy (Fig. 2). At the time of completing three cycles of chemotherapy, however, his testosterone level returned to the normal range with high of LH. This could also be accompanied by suppression of HCG. To confirm his hormonal remission, the endocrinological results of triple load tests after chemotherapy were compared with those before chemotherapy (Table 2 ). The ability of his pituitary to secrete hormones was grossly impaired before chemotherapy. This impaired ability was recovered to almost the normal pattern after chemotherapy. This reflected the successful withdrawal of maintenance hormone therapy (thyroxine and cortisol) in this patient.

\section{Discussion}

Conventional supervoltage irradiation has been known to be quite effective in the treatment of a "germinoma" type tumor, but to be relatively ineffective in the treatment of a "nongerminomatous" type tumor $[7,8,17-19]$. The radio-resistance of non-germinomatous germ cells in nature has led to the use of combination chemotherapy [8, 17-20]. Although long-term 
Table 2. Endocrinological evaluation of the patients' pituitary functions before and after treatment

\begin{tabular}{|c|c|c|c|c|c|c|c|c|c|c|c|c|c|c|}
\hline \multirow{2}{*}{\multicolumn{2}{|c|}{$\begin{array}{l}\text { Patient } \\
\text { No }\end{array}$}} & \multirow[b]{2}{*}{$\mathrm{DI}$} & \multicolumn{6}{|c|}{ Basal values } & \multicolumn{6}{|c|}{ Peak values during triple load test } \\
\hline & & & $\begin{array}{c}\mathrm{GH} \\
(\mathrm{ng} / \mathrm{m} l)\end{array}$ & $\underset{(\mu \mathrm{g} / \mathrm{d} l)}{\mathrm{F}}$ & $\begin{array}{c}\text { TSH } \\
(\mu \mathrm{u} / \mathrm{m} l)\end{array}$ & $\begin{array}{c}\mathrm{LH} \\
(\mathrm{ng} / \mathrm{m} l)\end{array}$ & $\begin{array}{c}\text { FSH } \\
(\mathrm{ng} / \mathrm{m} l)(\end{array}$ & $\begin{array}{c}\text { PRL } \\
(\mathrm{ng} / \mathrm{ml})\end{array}$ & $\begin{array}{c}\mathrm{GH} \\
(\mathrm{ng} / \mathrm{m} l)\end{array}$ & $\begin{array}{c}\mathrm{F} \\
(\mu \mathrm{g} / \mathrm{d} l)\end{array}$ & $\begin{array}{c}\text { TSH } \\
(\mu \mathrm{u} / \mathrm{m} l)\end{array}$ & $\begin{array}{c}\mathrm{LH} \\
(\mathrm{ng} / \mathrm{m} l)\end{array}$ & $\begin{array}{c}\text { FSH } \\
(\mathrm{ng} / \mathrm{ml})\end{array}$ & $\begin{array}{c}\text { PRL } \\
(\mathrm{ng} / \mathrm{ml})\end{array}$ \\
\hline \multirow[t]{2}{*}{1} & before & + & 1.2 & 9.8 & 2.6 & 4.8 & 2.8 & 65.0 & 2.7 & 20.2 & 9.4 & 14.6 & 8.6 & 74.2 \\
\hline & after & + & 1.6 & 5.1 & 2.9 & 4.5 & 3.4 & 114.1 & 1.6 & 11.8 & 3.7 & 5.2 & 5.2 & 114 \\
\hline \multirow[t]{2}{*}{2} & before & + & 1.5 & 1.6 & 2.0 & 9.2 & $<1.0$ & n.d..$^{(a)}$ & 1.8 & 3.7 & 6.1 & 21.0 & 4.8 & n.d..$^{(a)}$ \\
\hline & after & + & $<0.3$ & $<1.0$ & $<0.1$ & 0.8 & 1.4 & & $<0.3$ & $<1.0$ & $<0.1$ & 2.5 & 3.9 & n.d..$^{(a)}$ \\
\hline \multirow[t]{2}{*}{3} & before & + & 0.8 & $<1.0$ & 0.2 & $<0.5$ & $<0.5$ & 37.7 & 0.8 & $<1.0$ & 0.9 & $<0.5$ & $<0.5$ & 46.3 \\
\hline & after & + & 0.7 & 6.1 & $<0.1$ & $<0.5$ & $<0.5$ & 15.6 & 0.8 & 13.2 & $<0.1$ & 0.7 & $<0.5$ & 22.4 \\
\hline \multirow[t]{2}{*}{4} & before & + & 0.3 & n.d. ${ }^{(b)}$ & 3.2 & 3.3 & 5.4 & 6.0 & 1.0 & n.d. (b) $^{-}$ & 9.1 & 24.2 & 12.8 & 15.8 \\
\hline & after & + & $<0.3$ & n.d. ${ }^{(b)}$ & 1.4 & 2.6 & 3.3 & 11.5 & 0.4 & n.d. ${ }^{(b)}$ & 4.8 & 14.4 & 5.2 & 11.5 \\
\hline \multirow[t]{3}{*}{5} & before & + & 0.5 & 19.8 & 6.2 & $<0.5$ & 0.5 & 9.0 & 0.5 & 26.7 & 17.4 & 0.9 & 2.3 & 23.5 \\
\hline & after & + & 0.3 & 15.7 & 1.6 & 1.5 & 4.5 & 3.4 & 4.8 & 27.3 & 5.9 & 9.5 & 10.4 & 14.4 \\
\hline & mo after ${ }^{(c)}$ & + & 0.3 & 8.7 & & $<0.5$ & $<0.5$ & & & & & & & \\
\hline \multirow[t]{2}{*}{6} & before & + & 0.6 & 2.7 & 0.1 & $<0.5$ & $<0.5$ & 14.7 & 0.6 & 3.6 & 1.4 & $<0.5$ & $<0.5$ & 31.0 \\
\hline & after & + & 0.3 & 7.8 & 4.1 & 2.2 & 1.6 & 8.8 & 3.2 & 11.4 & 22.5 & 21.2 & 4.0 & 28.4 \\
\hline \multirow[t]{5}{*}{7} & before & & 0.3 & $<1.3$ & 0.6 & $<0.5$ & $<0.5$ & 11.2 & & & & n.d. (a) $^{-}$ & & \\
\hline & after & & 0.7 & $<1.0$ & $<0.1$ & $<0.5$ & $<0.5$ & 31.0 & 0.7 & $<1.0$ & $<0.1$ & $<0.5$ & 1.2 & 51.9 \\
\hline & normal ${ }^{(\mathrm{d})}$ & & & & & & & & & & & & & \\
\hline & male & - & $<5$ & $4-21$ & $0.4 \sim 5.6$ & $1.8 \sim 5.2$ & $2.9 \sim 8.2$ & $<10$ & $5-15$ & $8-30$ & $8-34$ & & & $20-70$ \\
\hline & female & - & $<5$ & $4-21$ & $0.4 \sim 5.6$ & $1.0 \sim 34.9$ & $2.0 \sim 14.4$ & $4<15$ & 5-15 & $8-30$ & $8-34$ & & & $30-85$ \\
\hline
\end{tabular}

The pituitary functions were evaluated by triple load tests before and immediately after treatments, (a), n.d.: not determined; (b), n.d.: not determined because this patient received a pharmacological dose of glucocorticoid; (c), these values were obtained 4 months after completing the primary radiotherapy; (d), normal values were for adult people.

follow-up studies have not sufficiently been made, excellent response rates have been reported when cisplaitin and etoposide were given to 12 patients with newly diagnosed or recurrent germ cell tumors, suggesting that this chemotherapy is successful in the treatment of both geninoma and non-germinatous germ cell tumors [12]. However, the effects of this chemotherapy on pre-existing hormonal abnormalities were not reported. Endocrine abnormalities have been known to be frequently associated with intracranial germ cell tumors $[4,5]$. Imura et al. reported that more than $80 \%$ of 256 patients with intracranial germ cell tumors manifest hypopituitarism [5]. A quite high incidence of hypopituitarism has been observed even though the primary tumors arise in the pineal region. This is consistent with our present observations. Another important endocrine abnormality in these tumors is DI. In the present study, both radiotherapy and chemotherapy failed to improve DI, suggesting that the neural cell damage was irreversible. This would be consistent with the finding that so-called porencephalus sometimes occurs in these patients (see Table 1). In addition, the abnormally high serum level of PRL was not lowered to the normal range in some patients even after complete remission was achieved by radiotherapy again, suggesting that their neural damage is irreversible.

Since intracranial germ cell tumors mainly occur in adolescents and young adults, a reversal of hormonal pertubations should be another important therapeutic target. The spectrum of hormonal abnormalities observed in this study was similar to the previously reported results $[4,5,22]$. The mechanism of hormonal pertubations observed in patients with these tumors appears as yet indefinite. Although the detailed mechanism of the germ cell tumor-induced hypopituitarism remains to be clarified, its reversibility throughout the patients' whole life is a clinically important question. Conventional irradiation of the sellar region has been known to damage the pituitary cells, reflecting the clinical observation that pre-existing hy- 


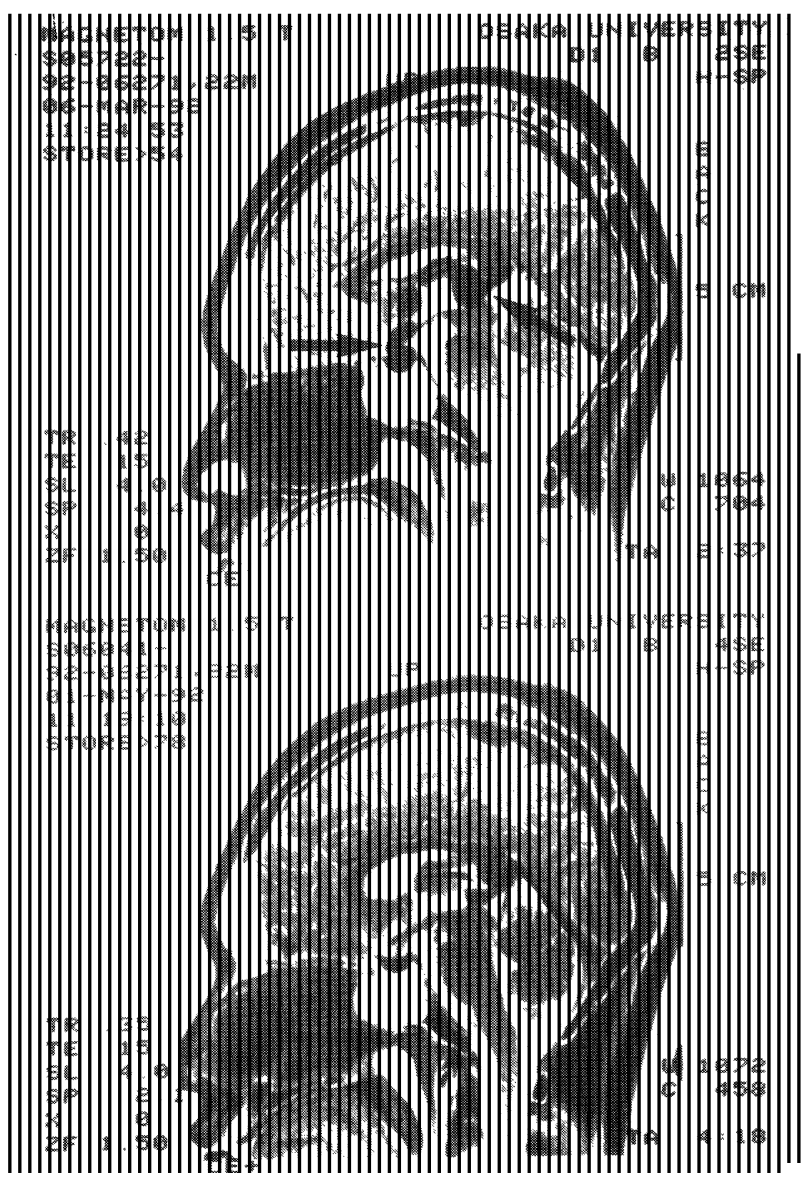

Fig. 1. Postcontrast MR of the brain before (upper) and after (lower) chemotherapy. Note that the enhanced mass shadows in the pineal and pituitary stalk region in Case 6 (indicated by the arrows) disappeared completely after the treatment.
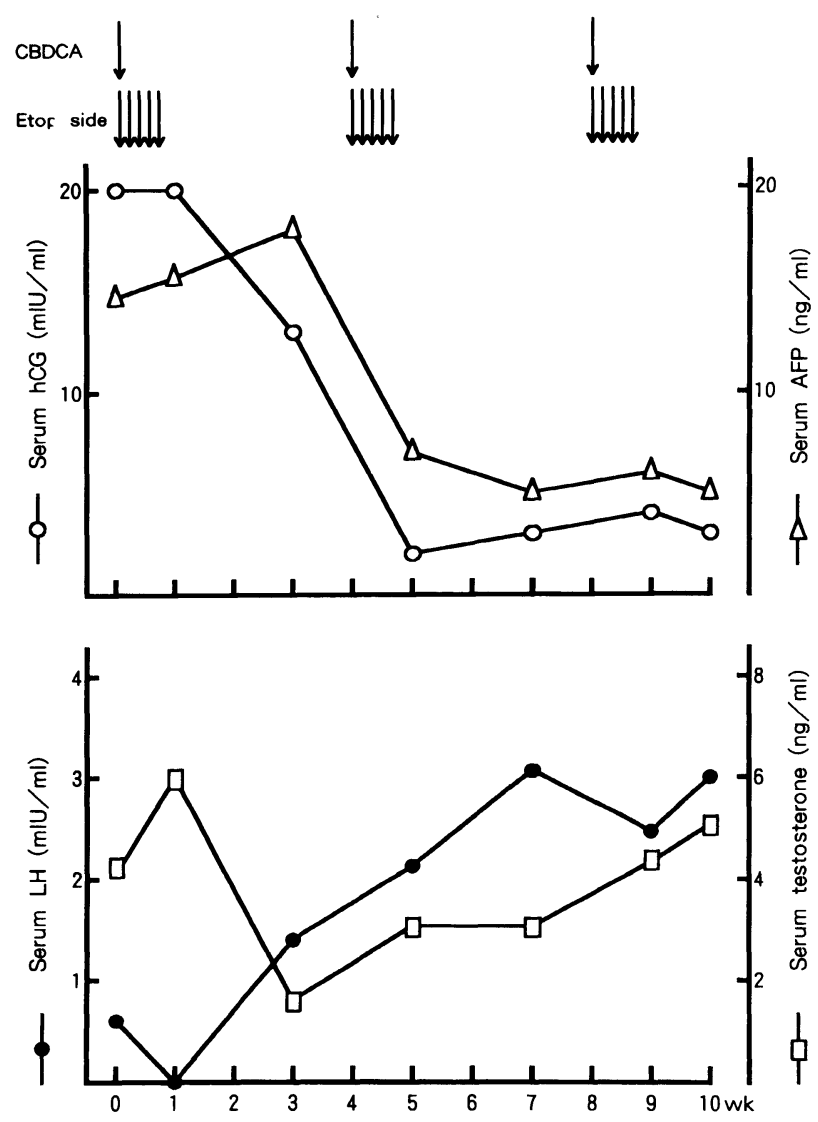

Fig. 2 Changes in serum HCG, AFP, LH, and testosterone levels in Case 6 during three cycles of combination chemotherapy. The serum levels of the tumor marker (upper panel) and pituitary-gonadal hormones (lower panel) were determined during the chemotherapy. popituitarism worsens after radiotherapy [9, 16]. Radiotherapy has also been known to induce late untoward effects such as a slowly progressing ablation of residual pituitary function [21]. This delayed radiation effect on pituitary function could explain why the recovery from hypoadrenocorticism in response to radiotherapy observed in Patient 3 was transient and subsequently required glucocorticoid replacement therapy. Among the patients treated with radiotherapy, Patient 5 showed a relatively good response in terms of her pituitary functions. Her impaired ability to secrete GH, LH and FSH was partly ameliorated after radiotherapy. Her improvement was again transient (see Table 2), resulting in panhypopituitarism two years after radiotherapy.

In contrast to this clinical experience of radiotherapy, hypopituitarism in Patient 6 appeared to be abolished after successful chemotherapy, indicating that hypopituitarism induced by intracranial germ cell tumors is reversible. We used CBDCA to reduce the nephrotoxicity of cisplatin. Etoposide, which was reported to be effective in treating malignant tumors [12, 24], was combined with CBDCA. However, it remains to be determined whether this combined chemotherapy is the most suitable in achieving oncological as well as endocrinological remission of germ cell tumors. These findings on hormonal remission are clinically important in this patient's achieving a normal 
sexual life. Impaired release of $\mathrm{GH}$, which frequently requires GH therapy to achieve normal growth in children treated by radiotherapy, may be ameliorated by chemotherapy. However, we observed chemotherapy-induced hormonal remission in only one case. Thus, the possibility should be taken into consideration that the present observations cannot be generalized. In future studies, it will be of interest to examine effect of chemotherapy as an initial therapeutic method on the hormonal remission in a large number of patients with intracranial germ cell tumors.

\section{References}

1. Jennings MT, Gelman R, Hochberg F (1985) Intracranial germcell tumors; natural history and pathogenesis. J Neurosurg 63: 1550-1567.

2. Sano K, Matsutani M (1981) Pinealoma (Germinoma) treated by direct surgery and postoperative irradiation. Child's brain 8: 81-97.

3. Gonzalez-Crussi $F$ (1982) Intracranial teratomas. In: Hartmann WH, Cowan WR (eds) Extragonadal Teratomas. Armed Forces Institute of Pathology, Washington D. C., 154-173.

4. Buchfelder M, Fahlbusch R, Walther M, Mann K (1989) Endocrine disturbances in suprasellar germinomas. Acta Endocrinol 120: 337-342.

5. Imura $H, K$ ato $Y$, Nakai $Y$ (1987) Endocrine aspects of tumors arising from supracellar, third ventricular regions. Prog Exp Tumor Res 30: 313-324.

6. Arita N, Ushio $Y$, Hayakawa $T$, Mori $S$, Bitoh $S$, Hasegawa H, Akagi K, Kano M, Oku H, Go J, Takimoto Y, Mogami H (1987) Role of tumor markers in the management of primary intracranial germ cell tumors. Prog Exp Tumor Res 30: 289-295.

7. Rich TA, Cassady JR, Strand RD, Winston KR (1985) Radiation therapy for pineal and suprasellar germ cell tumors. Cancer 55: 932-940.

8. Dearnaley DP, $\mathrm{A}^{\prime}$ Hern RP, Whittaker S, Bloom HJG (1990) Pineal and CNS germ cell tumors: Royal Marsden Hospital Experience 1962-1987. Int J Radiat Oncol Biol Phys 18: 773-781.

9. Eastman RC, Gorden P, Roth J (1979) Conventional supervoltage irradiation is an effective treatment for acromegaly. J Clin Endocri Metab 48: 931-940.

10. Hainsworth JD, Gerco FA (1983) Testicular germ cell neoplasms. Am J Med 75: 817-832.

11. Bajorin DF, Herr H, Motzer RJ, Bosl GJ (1992) Current perspectives on the role of adjunctive surgery in combined modality treatment for patients with germ cell tumors. Semin Oncol 19: 148-158.

12. Kobayashi $T$, Yoshida J, Ishiyama J, Noda $S$, Kito A, Kida Y (1989) Combination chemotherapy with cisplatin and etoposide for malignant intracranial germ cell tumors. J Neurosurg 70: 676-681.

13. Patel SR, Buckner JC, Smithson WA, Scheithauer BW Groover RV (1992) Cisplatin-based chemotherapy in primary central nervous system germ cell tumors. J Neur Oncology 12: 47-52.
14. Raaijmakers C, Wilms G, Demaerel P, Baert AL (1992) Pineal teratocarcinoma with drop metastasis: MR features. Neuroradiology 34: 227229.

15. Shinoda J, Yamada H, Sakai N, Ando T, Hirata T, Miwa Y (1988) Placental alkaline phosphatase as a tumor marker for primary intracranial germinoma. J Neurosurg 68: 710-720.

16. Koga $M$, Nakao $H$, Arao $M$, Sato B, Noma $K$, Morimoto Y, Kishimoto S, Mori S, Uozumi T (1987) Demonstration of specific dopamine receptors on human pituitary adenomas. Acta Endocrinol 114: 595-602.

17. Kawakami Y, Yamada O, Tabuchi K, Ohmoto T, Nishimoto A (1980) Primary intracranial choriocarcinoma. J Neurosurg 53: 369-374.

18. Kageyama N, Kobayashi T, Kida Y, Toshida J, Kato K (1987) Intracranial germinal tumors. Prog Exp Tumor Res 30: 255-267.

19. Edwards M, Hudgins R, Wilson C, Levin V, Wara W (1988) Pineal region tumors in children. $J$ Neurosurg 68: 689-697.

20. Allen JC, Jae HK, Packer RJ (1987) Neoadjuvant chemotherapy for newly diagnosed germ-cell tumors of the central nervous system. I Neurosurg 67: 65-70.

21. Duffer PK, Coher ME, Thomas PRM (1982) The long term effects of cranial irradiation on the central nervous system. Cancer 56: 1841-1846.

22. Pomarede R, Czernichow P, Finidori J, Pfister A, Roger M, Kalifa C, Zucher JM, Pirre-Kahn A, Rappaport R (1982) Endocrine aspects and tumoral markers in intracranial germinoma: An attempt to delineate the diagnostic procedure in 14 patients. $J$ Pediat 101: 374-379.

23. Bevan JS, Othman S, Lazarus JH, Pakers AB, Hall R (1992) Reversible adrenocorticotropin deficiency due to probable autoimmune hypophysitis in a woman with postpartum thyroiditis. J Clin Endocri Metab 74: 548-532.

24. Barlow JJ, Lele SB (1986) Etoposide (VP-16) plus cisplatin (DDP): A new active chemotherapeutic combination in patients with stage III-IV ovarian adenocarcinoma. J Surg Oncol 32: 43-47. 